\title{
KRIZA DEMOKRATSKOG KONSTITUCIONALIZMA I IZGLEDI DEMOKRATSKE TRANZICIJE U REPUBLICI HRVATSKOJ
}

Prof. dr. sc. Branko Smerdel *

UDK: $321.7(497.5)$

$342.413(497.5)$

DOI: 10.3935/zpfz.69.1.01

Izvorni znanstveni rad

Primljeno: prosinac 2018.

Ima ozbiljnih razloga za tvrdnju kako je povijest čovječanstva, kako se općenito opisuje i shvaća, ukupnost neočekivanih posljedica... Najmudriji su oni povjesničari koji priznaju da njihovo razmišljanje i zaključci mogu biti pogrešni.

Peter Acroyd, The History of England, 2011.

Kako bi bila jednako uspješna u 21. stoljeću, kao što je bila u 20. stoljeću, demokraciju treba pažljivo njegovati dok je mlada - i pažljivo održavati kada sazrije.

The Economist, What Went Wrong With Democracy, 2018.

Democracy is in crisis.

Freedom House on Democracy and Human Rights, 2018.

Velika očekivanja koja je donijela "ustavna revolucija" iz 1990. godine nisu se ostvarila. Teorija "demokratske tranzicije" od samog početka patila je od vidliivih slabosti: pretpostavke kako je u Europi i svijetu zaista uspostavljen novi poredak, utemeljen na altruizmu, solidarnosti, brizi za sveopći napredak $i$, iznad svega, na odricanju od uporabe sile. U tom procesu Hrvatska je jako kasnila zbog okolnosti koje je donijela agresija, pobuna, okupacija dijela teritorija i nužnost obrane su-

Dr. sc. Branko Smerdel, profesor Pravnog fakulteta Sveučilišta u Zagrebu, Trg Republike Hrvatske 14, Zagreb; branko.smerdel@pravo.hr;

ORCID ID: orcid.org/0000-0002-1836-1248 
vereniteta $i$ teritorijalne cjelovitosti kao primarna zadaća. Nove nade donijelo je punopravno članstvo u Europskoj uniji, ali samo kratkotrajno: tijekom dugogodišnjih priprema i pregovora, od Sporazuma o stabilizaciji i pridruživanju iz 2001. godine do potpisivanja Ugovora o pristupanju 2011. godine te punopravnog članstva 2013. godine, sama Europska unija bitno se promijenila, što se najizrazitije odražava na planu europskog konstitucionalizma i konstitucionalizma država članica. U sveopćoj regresiji $i$ redukciji očekivanja ne možemo očekivati potrebne $i$ bitne promjene $u$ Republici Hrvatskoj. Gledajući situaciju u europskim državama i na razini same Europske unije ne možemo se oteti dojmu kako se, nakon relativno kratkotrajnog prekida, temeljni koncepti demokracije i liberalnog konstitucionalizma nalaze na udaru klatna povijesti, koje se ponovno zanjihalo u suprotnom pravcu. Trijumfalni marš ustavnih revolucija, nošen dugo potiskivanim težnjama građanstva, zaustavljen je puzećim protuudarom konzervativnih nacionalističkih oligarhija, uspostavljenih na široko rasprostranjenom razočaranju što ga je donijela globalizacija, privatizacija i podvrgavanje države blagostanja interesima krupnog kapitala i diktaturom menadžmenta velikih korporacija. Gotovo su potpuno zaboravljena velika očekivanja što ih je donijelo rušenje "komunističkih" autokracija prije tridesetak godina. Pravna i politička teorija tek se okreće tom suštinskom problemu modernog svijeta izgrađenog na konceptima demokracije, konstitucionalizma, vladavine prava $i$ promicanja ljudskih prava. Vrijeme je da se i u Hrvatskoj okrenemo pokušajima sinteze $i$ razmotrimo kako očuvati temelje tek uspostavljenog konstitucionalizma $i$ zaista nezrele "nove demokracije". Autor smatra kako će ustupci i promjene biti nužni, ali odlučno naglašava stav da poželjne alternative nema.

Ključne riječi: kriza, konstitucionalizam, demokracija, Europska unija, Hrvatska

\section{OD NAGOVJEŠTAJA "KRAJA POVIJESTI" DO PONOVNO PRIJETEĆEG "ARMAGEDONA"}

Iznenadni slom komunističkih režima putem niza "ustavnih revolucija” bio je proglašen "krajem povijesti” kakvu je čovječanstvo do tada poznavalo: povijest ratova, nacionalizma i ratobornog suparništva. Sukobe i rivalitete među državama i ljudima zamijenit će, počevši od proslavljene Godine čuda (Annus mirabilis), kraj svih konflikata i ratova, novi svijet kooperacije i mirnog života u nastojanju na zajedničkom napretku čovječanstva. ${ }^{2}$ Ugledni američki ustavni teoretičari zanosili su se sličnom vrstom iluzija: “Od Varšave do Moskve, od Havane do Pekinga, duh koji kao da je ustao iz groba kruži svijetom - povratak

1 Jedna ranija verzija ovog rada izrađena je u sklopu istraživačkog projekta Novi hrvatski pravni sustav Pravnog fakulteta Sveučilišta u Zagrebu za 2018. godinu.

2 Nakon pobjede saveznika u Pustinjskoj oluji 1990. predsjednik SAD-a George W. Bush, stariji, proglasio je uspostavljanje "novog svjetskog poretka”. Već 1994. Zbignew Brzezinski odgovara knjigom Out of Control i upozorava da je u svijetu ustvari nastao novi nered - "a new world disorder". 
revolucionarnoga demokratskog liberalizma”, pisao je Bruce Ackerman, parafrazirajući poznatu prvu rečenicu Komunističkog manifesta iz 1848. godine. ${ }^{3}$ Bio je to vrhunac naizgled ireverzibilnog procesa nastupanja demokracije kao dominantnog tipa političkog sustava. ${ }^{4}$

Raniji valovi demokratizacije u Europi potvrđivali su, činilo se, najoptimističnija očekivanja. Nakon značajnih tranzicija prema demokraciji tijekom obnove ustavnog poretka u državama poraženim u II. svjetskom ratu uslijedilo je razdoblje prividnog mira, u kojem su stabilne demokracije nadzirale napredak dojučerašnjih neprijatelja i istodobno podupirale stabilizirane autokratske režime crnih zastava u južnoj Europi. U suočavanju s izazovima razdoblja hladnoga rata u srednjoj i istočnoj Europi, odijeljenoj “željeznim zastorom”, Sovjetski Savez nije oklijevao od prijetnji ili stvarnih oružanih intervencija, u slučajevima ugrožavanja "ograničenog suvereniteta" unutar suprotstavljenog svijeta "socijalističkih” autokracija, kao u Mađarskoj 1956., Čehoslovačkoj 1968. godine, ali i u Poljskoj 1981. godine, kada je uspostavljanje vojne vlasti takvu intervenciju bitno otežalo, pa se od nje i odustalo. ${ }^{5}$

Eksperimentiranje sa “socijalističkim samoupravljanjem” u federativnoj Jugoslaviji nije ozbiljnije uspjelo utjecati na ideološke bastione koji su priječili zbiljsko demokratsko otvaranje, kao u slučaju Hrvatskog proljeća 1972. godine. Brojne reformske ustavne i zakonske promjene tijekom više desetljeća eksperimentiranja bile bi svaki put zaustavljene onog trenutka kada bi partijska autokracija bila dovedena u pitanje. ${ }^{6}$

Polovicom sedamdesetih godina 20. stoljeća, padom dugogodišnjih autokracija, počeo je naizgled nezaustavljivi "marš demokracije”. Od revolucije karanfila

3 Ackerman, B., The Future of Liberal Revolution, Yale University Press, 1992. Recenzija Richarda Posnera u East European Constitutional Review, vol. I, br. 3, 1992., str. $35-36$.

4 Elster, J.; Slagstad, R. (ur.), Constitutionalism and Democracy, Cambridge University Press, 1988.; Ahdieh, R., Russia's Constitutional Revolution: Legal Consciousness and the Transition to Democracy, Pennsylvania State University Press, 1997.; naš tekst u prvom izdanju udžbenika Sokol, S.; Smerdel, B., Ustavno pravo, Školska knjiga, 1992., str. 34.

5 Pokušavajući klasificirati države toga naizgled nepromjenjivog svijeta klasičnih "liberalnih" demokracija i "radničkih" demokracija novoga tipa Georges Burdeau razvio je tipologiju vladajućih demokracija "otvorenog” i "zatvorenog” tipa (Traite de science politique, vol. 4, L. G. D. J., 1952., str. 441 - 487). Prijevod Daša Bradičić u: Mratović, V., Problemi suvremene države, Naprijed, 1971., str. 133 - 180.

6 Smerdel, B., Ustavni eksperiment socijalističkog samoupravljanja, Zbornik Pravnog fakulteta u Zagrebu, vol. 38, br. 3, 1988., str. 317 - 333. 
u Portugalu 1974. godine, monarhijske revolucije u Španjolskoj 1978., kao i pada vojne diktature u Grčkoj 1974. godine, glavnu ulogu je odigrao "narod", u smislu najšireg pučanstva (the People). Građani ruše vlast postavljajući masovne zahtjeve na trgovima i ulicama te, u interakciji s drugim ključnim čimbenicima, kao što su vojska i snage sigurnosti, uspostavljaju nove višestranačke sustave, kompetitivnim izborima formiraju parlamente i započinju političko djelovanje na način koji je dugo vremena bio suspendiran ili uopće nije postojao u novim demokracijama. Očekivalo se to dugo, ali nitko, ni znanstvenici ni obavještajne službe, nisu predvidjeli takav prolom socijalnog revolta, poput iznenadnog potresa velikih razmjera: rušenja socijalističkih autokracija, putem domino efekta, nizom "ustavnih revolucija".

Rušenje autokratskih režima korištenjem sredstava izbora i novog zakonodavstva nastavljalo se, ne bez uspona i padova, sve do propagandnog proglašenja arapskog proljeća, koje je 2011. godine zahvatilo niz država u kojima su prevladavale autokratske ili vojne vlade: od Tunisa do Egipta, Libije i Sirije. ${ }^{7}$ No, ovo "demokratsko buđenje" u državama koje nikada nisu ni upoznale demokraciju, premda su neke iz orijentalnih despocija prerasle u diktature doživotnih predsjedničkih dinastija, nije za posljedicu imalo uspostavljanje demokratskih poredaka. ${ }^{8}$ Rušenje Mubarakova režima u Egiptu predstavljalo je tek kratku "demokratsku" međuigru do ponovnog uspostavljanja vojnog režima, uz potporu Sjedinjenih Američkih Država tom dugogodišnjem obliku jamstva za održanje mira s Izraelom. Libijski režim pukovnika Gadafija ostao je bez saveznika i bio brzo poražen, što je za posljedicu imalo raspad vojske i države te međusobno ratovanje frakcija i sekti. U Siriji je pak došlo do građanskog rata i vojne intervencije u cilju zaštite ruskog saveznika predsjednika Bašara al-Asada. Rat u Iraku, u različitim oblicima, traje neprekidno od rušenja diktatora Sadama Huseina, uz vanjske poticaje, pa i izravne intervencije protiv Kurda.

Mi ne možemo ni pokušati opisati svu složenost nastale situacije, ali to nam nije ni namjera. Bitno je naglasiti kako su se propagandna očekivanja da će narodi spomenutih zemalja slijediti pravce "demokratske tranzicije" pokazala potpuno pogrešnima u državama kojima se nikada ni nije upravljalo na demokratski način. Umjesto toga, rušenje autokratskih režima imalo je

7 Vidi radove objavljene u časopisu Političke analize, vol. 3, br. 11, 2012., odjeljak $U$ žarištu: Arapsko proljeće, Islam i demokracija; Mecham, Q., Jačanje islamističkih aktera: prijedlozi za američku strategiju održive suradnje, Političke analize, vol. 3, br. 11, 2012., str. 26 - 30; Picula, B., Božja stranka na čelu Libanona - od rata do vlasti, Političke analize, vol. 3, br. 11, 2012., str. $30-37$.

8 Poput nekoliko bivših sovjetskih republika kojima su zavladale dinastije moćnih članova posljednjeg Politbiroa SKPB-a. 
za posljedicu masovni egzodus milijuna ljudi prema Turskoj, Grčkoj, Italiji, Hrvatskoj i drugim zemljama, na putu prema "obećanom blagostanju” u zapadnoj Europi. Je li netko od donositelja ključnih odluka u tim događanjima zaista vjerovao kako će, nakon vojnih intervencija, doći do širenja procesa "demokratske tranzicije", po uzoru na onu kroz koju prolaze postkomunističke zemlje i Hrvatska?

\section{ANNUS MIRABILIS, USTAVNE REVOLUCIJE I UBRZANE "DEMOKRATSKE TRANZICIJE"}

U Hrvatskoj, kao i u drugim postkomunističkim državama istočne i srednje Europe, težnje ka ubrzanim promjenama gospodarskog, pravnog i političkog sustava, a time i fundamentalnim promjenama društvenog života, usredotočene

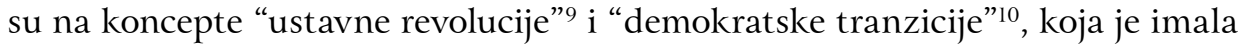
uslijediti s ciljem ubrzanog prevladavanja jaza između razvijenog zapada i novih demokracija.

Unatoč cinizmu prema obećanjima boljeg budućeg svijeta stvari su se sada činile mnogo jednostavnijima, najavljujući svojevrsnu "slavnu revoluciju”. Naime, nasuprot utopističkim idejama ranijih revolucija, orijentiranih na građenje novih svjetova koji nikada nisu postojali, sada se ciljalo na imitaciju zapadnih liberalnih demokracija, predviđala se "revolucija trijeznih očekivanja”, kako je konzervativni kritičar nazvao još američku Revoluciju. ${ }^{11}$ Dapače, očekivala se nesebična pomoć i savjet naprednih društava koje se željelo imitirati, u interesu osiguravanja mira i zajedničkog napretka, po uzoru na europske integracije. Počeo je proces "demokratske tranzicije"12 i malo tko

9 Smerdel, B., Central European Democratic Transition: The Paradigm of Constitutional Revolution, Paper presented at the Round Table of the International Association of Constitutional Law, Belgrade, Serbia, May 2012.

10 Basta Fleiner, L.; Marinković, T. (ur.), Central European Democratic Transition. The Paradigm of Constitutional Revolution, Key Developments in Constitutionalism and Constitutional Law, Eleven International Publishing, 2014., str. 63 - 83.

11 Diamond, M., The Revolution of Sober Expectations, predavanje dostupno na: www.aei.org/publication/the-revolution-of-sober-expectations, Oct 24, 1973 (1. prosinca 2018.); Raunić, R., Edmund Burke: Razmatranja o revoluciji u Francuskoj, dostupno na: http://www.ffzg.unizg.hr/filoz/wp-content/uploads/2011/11/Raunic\%CC\%81_E.-Burke.pdf (1. prosinca 2018.).

12 Oxford Manifesto 1997 of the Liberal Internationale, The Liberal Agenda for the 21st Century, dostupno na: https://liberal-international.org/who-we-are/...manifestos/oxford-manifesto-1997/ (1. prosinca 2018.). 
se usuđivao upozoravati na oprez, a posebno ne pozivati na učenje iz grešaka počinjenih u prošlosti. ${ }^{13}$

Dakako, oslonac tih očekivanja i nada bila je Europska unija, na početku tisućljeća na vrhuncu snage i naizgled iznimno svijetlih perspektiva, koja je počela djelovanje na uspostavljanju novog ustava kao odgovora na kronične probleme "demokratskog deficita", s istaknutim ciljem "sve bližeg ujedinjenja". U Hrvatskoj javnosti, pa i u radovima sa znanstvenim pretenzijama, proširila se ideologija "novog tipa međudržavne zajednice", utemeljene na europskim načelima, i lišene egoizma i dominacije velikih i snažnih nad malima i slabijima. ${ }^{14}$

Mi smo vrlo rano upozoravali na oprez u pogledu takvih ekstenzivnih očekivanja: ne samo da je očekivati dugotrajnu altruističku pomoć razvijenijih država bilo protivno temeljnim aksiomima povijesno-političkih znanosti, kao i povijesnom iskustvu, nego je to posebno u suprotnosti sa zakonitostima tržišnog gospodarstva, koje nameće imperativ rasta, tako da nužno vodi osvajanju novih tržišta i nastojanju na monopolističkoj dominaciji tim tržištima. Pomoć međunarodne zajednice bila je važna za preživljavanje, uspostavu mira, pa i inicijalnu izgradnju institucionalnog sustava. Međutim, postupno se potvrdilo povijesno iskustvo kako glavni odlučujući faktor čine interesi, a ne altruizam. Sukladno našem uvjerenju kako znanstvene spoznaje imaju biti dostupne širokom krugu donositelja političkih odluka, aktualnih i budućih, na to smo opetovano upozoravali u radovima objavljivanim i na engleskom i na hrvatskom jeziku. ${ }^{15}$

Prevladavalo je uvjerenje o dugoročno potpuno izvjesnoj pobjedi liberalnog konstitucionalizma i demokracije nad autokracijama različitih ideoloških boja i predznaka. Smatralo se kako je uspjeh zajamčen jer je riječ o normalizaciji, vraćanju političkih i gospodarskih institucija i cjelovitih sustava konceptima organizacije primjerenim ljudskoj naravi, nakon neuspjeha surovog socijalnog eksperimentiranja in vivo tijekom dugih desetljeća dominacije socijalističkih autokracija u velikom djelu svijeta, bez obzira na žrtve. Istini za volju, i naše pogrešne procjene da će recepcija konstitucionalizma u Hrvatskoj teći mnogo brže nego što je to doista slučaj bile su uvjetovane većinskim uvjerenjem kako će se "stvari lakše vratiti u normalu", premda smo, s obzirom na povijesne i

13 Smerdel, B., Kraj tranzicije i nužnost konsolidacije ustavnog poretka, Hrvatska pravna revija, br. 8, 2012., str. $2-5$.

14 Smerdel, B., Primjena federalnog načela i ustavni amandmani iz 1971. u: Smerdel, B. (ur.), Primjena federalnog načela i pouke ustavne reforme 1971., Pravni fakultet Zagreb i Centar Miko Tripalo, 2007., str. 17 - 38.

15 Smerdel, B., Ustavna revolucija, demokratska tranzicija i vladavina prava u: Uzelac, A.; Garašić, J.; Maganić, A. (ur.), Djelotvorna pravna zaštita u pravičnom postupku, Liber amicorum Mihajlo Dika, Pravni fakultet u Zagrebu, 2013., str. 27 - 45. 
komparativne uvide, uočavali poteškoće. ${ }^{16}$ U ozračju općeg entuzijazma teško je postalo koristiti komparativne uvide u zbiljsko funkcioniranje naših uzora, "zrelih demokracija”. Korupcija, nezakonitosti, goleme korporativne prevare (i) u tim državama opravdavale su razorno djelovanje divljeg kapitalizma u Hrvatskoj. ${ }^{17}$

Nakon dva i pol desetljeća, odnosno, točnije, više od četvrt stoljeća inzistiranja na tranziciji, praćenog stalnim pozivanjem na reforme kao panaceju, univerzalni lijek koji se preporučuje dezorijentiranim političkim vodstvima bankrotiranih novih, ali i dijela starijih demokracija, postupno prodire shvaćanje kako očekivanja u pogledu demokratskih tranzicija nisu definitivno propala, ali je u pitanju ozbiljna kriza u kojoj se mogu nazrijeti takve mogućnosti. ${ }^{18}$

16 To se odražava u gradaciji ocjena i upozorenja u našim radovima: 1) najoptimističnije: Konstitucionalizam i promjena vlasti, Zbornik Pravnog fakulteta u Zagrebu, vol. 50, br. 1-2, 2000., str. 5 - 28; 2) umjereno optimistično: Promjena vlasti i izgledi ustavnog poretka u: Kregar, J.; Ravlić, S. (ur.), Hrvatska: Kamo dalje?, Centar Miko Tripalo, Zagreb, 2004., str. 192 - 193; 3) s umjerenim optimizmom: Smjena vlasti, demokracija i vladavina prava, Informator, br. 6027 od 10. prosinca 2011., str. 1 - 2; te na kraju 4) krajnje pesimistički: Hrvatski konstitucionalizam danas. U svijetlu Prijedloga ustavnih promjena, Informator, br. 6249 od 25. siječnja 2014., str. 1 - 2.

17 Npr. zaobilaženje ekološke regulacije pomoću lažnih mjerača zagađenja u najvećim svjetskim korporacijama, dogovaranja burzovnih indeksa u najznačajnijim bankama te masovno subprime kreditiranje hipotekarnih zajmova u najvećim svjetskim bankama. Ali i dugogodišnje toleriranje lažnih financijskih izvješća europskih vlada, na prvom mjestu grčke, koje je dovelo do krize eurozone i neformalnog uspostavljanja "bankovne unije”.

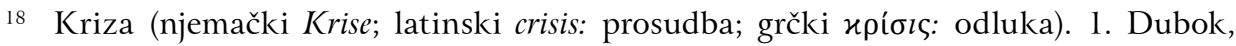
sveobuhvatan poremećaj u životu pojedinca ili funkcioniranju društva sa snažnim i više ili manje teškim i trajnim posljedicama; prijelomno, prolazno teško stanje (društvena, politička kriza, ekonomska kriza). 2. U vojnom značenju, stanje povećanog intenziteta neprijateljskoga djelovanja između dvaju ili više protivnika s velikom mogućnošću izbijanja oružanoga sukoba. Obično se brzo razvija i od takve je političke, diplomatske, gospodarske ili vojne važnosti da umiješane strane smatraju opravdanom uporabu vojnih snaga i sredstava za postizanje nacionalnih ciljeva. Zbog teških i dugotrajnih posljedica što ih krize mogu imati na sigurnost i stabilnost pojedine države, regije ili na svjetskoj razini, predviđanje i upravljanje krizom jedna je od najvažnijih zadaća međunarodne zajednice. 3. U medicini, prijelomna faza u tijeku akutne bolesti (npr. zarazne s visokom vrućicom), ili iznenadno pogoršanje neke kronične bolesti. Od pojave krize bolesnikovo se stanje može poboljšati (obično kod akutnih bolesti), ili pogoršati. Krizno duševno stanje prolazni je psihički kolaps i emocionalni odgovor na neki sukob (npr. akutna potištenost uz strah i klonulost, ili sumorna napetost s mislima o samoubojstvu). 4. U filozofiji, stanje sporenja mišljenjâ ili konflikta koje završava donošenjem nekoga konačnoga suda, odnosno odluke. Prema: http://www.enciklopedija.hr/ natuknica.aspx?id=34066 (1. prosinca 2018.), skratio B. S. 
Dapače, sve je više teoretičara, kao i istraživača, sklono tvrdnji kako, uslijed neočekivanih zastrašujućih izazova, prijeti slom i starim državama, nositeljima liberalnog konstitucionalizma. ${ }^{19}$

Dosljedni čuvar liberalnih ideja, vladavine prava, liberalizma u gospodarstvu i liberalnih političkih sustava časopis The Economist još u ožujku 2014. godine, u dugačkom eseju, postavlja pitanje: "Što je to pošlo krivo s demokracijom i kako je možemo oživjeti?”. ${ }^{20}$ U rujnu 2018. godine, u prigodi obilježavanja 175. godišnjice izlaženja, ne prihvaćajući defetističke ocjene o njegovoj mogućoj propasti, naglašava trajne čovječanske vrijednosti demokracije i konstitucionalizma, poziva na njihovu obranu i obnovu te objavljuje dramatični "Manifest za obnovu liberalizma”. ${ }^{21}$

\section{EUROPA: UGROŽEN JE MIR I GOSPODARSKI NAPREDAK}

Dinamiku ustavnog i političkog procesa u Republici Hrvatskoj ne određuju isključivo, pa ni pretežito, unutarnji čimbenici. Kriza ustavnosti, odnosno kriza sustava koji je uspostavljen teškom mukom postignutim Lisabonskim sporazumom karakterizira odnose unutar Europske unije. Formalno održavanje

Crisis: 1.a stage in a sequence of events at which the trend of all future events, especially for better or for worse, is determined; turning point. 2.a condition of instability or danger, as in social, economic,political, or international aff airs, leading to a decisive change. 3.a dramatic emotional or circumstantial upheaval in a person"s life. Prema: http://www.dictionary.com/browse/crisis (1. prosinca 2018.).

19 Ginsburg, T.; Huq, A.; Versteeg, M., The Coming Demise of Liberal Constitutionalism?, The University of Chicago Law Review, vol. 85, br. 2, 2018., str. 239 - 255.

20 The Economist, March 1-7, 2014., str. 43 - 48. Interaktivni esej na economist/com/ democracy s jedne strane ukazuje na ozbiljnost problema, a s druge strane na ograničeni doseg ideja i sredstava obnove.

21 The Economist, September 15-21, 2018., str. 41 - 52, priziva a liberal revival-a liberalism for the people, echoing similar calls for democratic renewal. In one flavor or another, liberal democracy came to dominate the West and from there it started to spread around the world. Yet political philosophies cannot live by their past glories: they must also promise a better future. And here liberal democracy faces a looming challenge. Western voters have started to doubt that the system works for them or that it is fair. In polling last year just $36 \%$ of Germans, 24\% of Canadians and 9\% of the French thought that the next generation would be better off than their parents. Only a third of Americans under 35 say that it is vital they live in a democracy; the share who would welcome military government grew from 7\% in 1995 to 18\% last year. Globally, according to Freedom House, an NGO, civil liberties and political rights have declined for the past 12 years - in 2017, 71 countries lost ground while only 35 made gains. 
uspostavljenih institucija, odnosno pridržavanje procedura, ne mijenja činjenicu da je odnos snaga unutar Unije bitno drukčiji nego u vrijeme donošenja Ustava EU-a 2004. godine, čije se ostatke ostataka nastojalo očuvati Lisabonskim sporazumom. Pod udarom financijske krize koja je zaprijetila nizu država članica već 2010. godine predlagane su promjene Lisabonskog sporazuma, zatim 2011. produbljene promjene, da bi nakon toga dinamika krize država eurozone nametnula niz ad hoc rješenja kao što je nadzor nad državnim proračunima od strane Središnje banke. Općeprihvaćeno je stajalište posljednjih godina kako se Europskom unijom upravlja iz ureda njemačke kancelarke. ${ }^{22}$

Kriza demokratskih sustava i jačanje populizma u nizu zemalja dovodi do odluke britanskih birača na referendumu od 26. lipnja 2014. godine da ova velika i važna država napusti Europsku uniju. Zaoštrava se najteža kriza Unije, koja dovodi u pitanje sam njezin opstanak, pa čak i održavanje temeljnih ciljeva i nedvojbenih postignuća europskih integracija, a to su "peace and prosperity", mir koji je uspješno održavan duže nego ikada prije u europskoj povijesti, te je omogućio ubrzani napredak europskim državama.

$\mathrm{Na}$ te temeljne ciljeve je, uostalom, na osebujan način upozorio Norveški odbor za Nobelovu nagradu 2012. godine, dodjeljujući Nobelovu nagradu za mir Europskoj uniji. ${ }^{23}$ Bilo je to vrijeme revolta protiv strogih mjera štednje, kojima je uvjetovana financijska pomoć Grčkoj, kada su se na ulicama nosili transparenti protiv Nijemaca, s reminiscencijama na okupaciju tijekom II. svjetskog rata. ${ }^{24}$ No, situacija se od tada nije u biti promijenila, na što upućuje uporno inzistiranje uzastopnih poljskih vlada na ratnim reparacijama od Njemačke. ${ }^{25}$

22 Europska komisija, Bijela knjiga o budućnosti Europe, 1. ožujka 2017., dostupno na: https://ec.europa.eu/commission/sites/beta-political/files/bijela_knjiga_o_buducnosti_europe_hr.pdf (1. prosinca 2018.).

23 Na alarmantno stanje duhova, posebno u studenome 2011., upućivale su izjave o mogućnostima novog rata u Europi. One nisu dolazile od maštovitih kolumnista nego od ozbiljnih insidera u pogledu povijesti ratovanja, kao i u pogledu zatomljenih, ali nezaboravljenih europskih raskola. Američki general M. Dempsey o mogućnosti raspada Europske unije i mogućnosti rata u Europi, http://danas.net.hr/svijet/ page/2011/12/11/0052006.html. Poljski ministar vanjskih poslova J. Rostowski, http://videoteka.novatv.hr/multimedia/iz-vijesti-u-17-moguc-novi-rat-u-europi.html (9. ožujka 2012.).

24 Grčka kriza izaziva revolt i kršenje prava | Dužnička kriza | Al Jazeera balkans, aljazeera.net /.../grcka-kriza-izaziva-revolt-i-krsenje-prava (28. travnja 2013.).

25 Poljska ustraje na isplati reparacije od Njemačke, Jutarnji list, 28. 10. 2018., https:// www.jutarnji.hr/vijesti/svijet/poljska-ustraje.../7992008/; Njemačka će Poljskoj platiti ratnu odštetu? - tportal, https://www.tportal.hr/.../njemacka-ce-poljskoj-platiti-ratnu-odstetu (17. siječnja 2018.). 
Kao da se klatno povijesti neumoljivo vraća natrag, nakon velikog zamaha u pravcu demokratizacije, sada u povratnom zamahu čija je krajnja točka prijetnja povratka autokratskih poredaka. Plimni val demokratizacije donio je početkom novog tisućljeća pravu poplavu oduševljenja na području društvenih znanosti, koja je trajala i kada su znakoviti pokazatelji upućivali na to da novi svjetski poredak zahtijeva nove definicije.

Malobrojni su odmah upozorili kako napad terorista na New York i Washington 2001. godine znači bitnu prekretnicu za cijeli svijet. Započeo je rat sui generis, koji su teroristi nastojali prikazati kao rat civilizacija, kakav je predviđao Samuel Huntington. ${ }^{26}$ Kao posljedica toga usvojeni su vrlo ozbiljni zakoni o sigurnosti i iznimno ojačan aparat "domovinske sigurnosti". Uslijedile su i prolongirane vojne intervencije Amerikanaca i njihovih saveznika u Aziji i Africi, dok su teroristički napadi na velike europske gradove polovicom prvog desetljeća 21. stoljeća (Pariz, London, Madrid, Stockholm i niz drugih) zahtijevali nužne mjere jačanja sigurnosnih sustava u državama duge liberalne demokracije. ${ }^{27}$

Osim strogog antiterorističkog zakonodavstva neke od tih mjera, po uzoru na američku praksu, značile su takve povrede ustaljenih postulata međunarodnih izvora ljudskih prava, pa i suvremenog prava ratovanja, koje su definitivno pokazale da proces demokratizacije i konstitucionalizacije politike ni u kojem slučaju nije ireverzibilan. ${ }^{28}$ Odbor za dodjelu Nobelove nagrade pokušao je tada ponovno potaknuti obećane političke odluke o završetku rata u Afganistanu i zatvaranju zarobljeničkog centra Guantanamo na način da je, anticipirajući uspjeh, Nobelovu nagradu za mir 2008. godine dodijelio novom američkom predsjedniku Baracku H. Obami. Nota bene, nagrada novom američkom predsjedniku bila je dodijeljena i prihvaćena za samo obećanje, to jest unaprijed, radi ohrabrenja, i teško je kazati što je prevagnulo kod njezina donošenja. Ali predsjednik Obama u dva svoja mandata nije uspio ostvariti ta ključna obećanja. ${ }^{29}$

Nakon početka oružanog sukoba između Rusije i Ukrajine te ponovnog dramatičnog stupanja ruskih oružanih snaga na svjetsku scenu vojnom intervencijom na strani Asadova režima u Siriji, i to ne kao ogromne zastarjele armade,

26 Huntington, S., The Clash of Civilizations and the Remaking of World Order, Simon \& Shuster, 1997. Vidi Samuel P. Huntington: A prophet of the Trump Era, www. washingtonpost.com/news/book-party/wp/ (18. srpnja 2017.).

27 Ginsburg, T.; Huq, A. Z., How to Save a Constitutional Democracy, University of Chicago Press, 2018., str. 3 - 9.

28 Koh, H. H., Can the Commander in Chief Be the Chief Torturer?, Indiana Law Journal, vol. 81, 2006., str. 1145 - 1167.

29 Kako je Obama nastojao ispuniti dana obećanja i zašto u tome nije uspio iznimno temeljito u: Woodward, B., Obama's Wars. The Inside Story, Simon \& Shuster, 2010. 
kako su se još 2008., nakon kratkotrajnog rata s Gruzijom, podrugivali zapadni mediji, nego kao moderne supersile suprotstavljene NATO-u, postalo je jasno kako ni Europska unija neće moći izbjeći novu konfrontaciju.

To se, dakako, odrazilo i u Hrvatskoj, koju su gospodarske sankcije protiv Rusije skupo stajale u već ionako teškoj gospodarskoj situaciji. Protumjere NATO-a, razmještanjem vojnih snaga u baltičkim državama, stvaraju novu ravnotežu straha u kojoj konstitucionalizam dolazi u drugi plan. ${ }^{30} \mathrm{U}$ studenome 2018. godine francuski predsjednik Emmanuel Macron zalaže se za brzo uspostavljanje europske vojske, koja bi preuzela punu odgovornost za obranu Europske unije izrijekom rečeno “od Rusije!". ${ }^{31}$ Umirovljeni sovjetski vođa Mihail Gorbačov, kao osobito važan akter, ali i svjedok procesa otvorenog (i) njegovim odlukama, o tome zaključuje: "Mogućnosti, koje su se pojavile nakon završetka hladnog rata, bile su propuštene. Nisu iskorištene onako kako su se morale iskoristiti. Raspad Sovjetskog Saveza, koji je bio izazvan unutarnjim razlozima, mnogi su na zapadu dočekali s likovanjem. Završetak hladnog rata, koji je odgovarao i jednoj i drugoj strani te čitavom svijetu, objavljen je kao pobjeda zapada i SAD-a. Na kraju svijet nije postao ništa manje opasno mjesto. Umjesto "svjetskog poretka" dobili smo "globalni nemir". Sukobi se nisu samo pojavili u zemljama trećeg svijeta nego i u Europi. A sad se oružani sukob pojavio doslovno pred našim vratima." 32

Val ekonomske krize, uzrokovan spekulacijama najjačih financijskih korporacija svjetskog poretka, koji se 2008. godine poznatom, ali potisnutom snagom gospodarskih kriza kapitalizma proširio svijetom, definitivno je pokazao kako Europska unija i Hrvatska trebaju novu paradigmu kao podlogu strategije modernizacije. ${ }^{33}$ Dakako, u tom pogledu, kako je početkom tisućljeća opominjao Zbigniew Brzezinski, golem teret odluke leži na predsjedniku Sjedinjenih Američkih Država, to jest, u to vrijeme gotovo nepredvidljivoj, pojavi milijardera poduzetnika Donalda Trumpa na toj funkciji. ${ }^{34}$

30 Gorbačov: Hladni rat nikad nije ni prestao, Sputnjik Srbija, https://rs-lat.sputniknews.com/.../201809131117171716-gorbacov-... (13. rujna 2018.).

31 Macron: 'Europi treba prava Europska vojska, da nas brani od Rusije' | 24sata, https://www.24sata.hr/.../ (1. prosinca 2018.).

32 Vidi https://hr.rbth.com/opinion/2015/03/21/ekskluzivan_clanak_gorbacova_o_perestrojci_33793, 2015. (1. prosinca 2018.),

33 Nacional: Tko je kriv za fašizam 21. stoljeća, Rob Riemen, robriemen.nl/publicitet/ nacional/ (1. prosinca 2018.). 


\section{KRIZA KONSTITUCIONALIZMA U EUROPI I KRIZA EUROPSKOG KONSTITUCIONALIZMA}

Kada pogledamo stanje Europske unije, golema je razlika između situacije početkom trećeg milenija, kada je Laekenska deklaracija naglašavala kako su europske integracije "priča o uspjehu", a politička klasa hitala donijeti novi ugovor, ili čak, nadajući se ponavljanju "čuda iz Philadelphije”, novi Ustav Europske unije, i današnje situacije dvadeset godina kasnije, kada se razmatra pet scenarija o budućnosti Unije, od kojih jedan predviđa i mogućnost raspuštanja. ${ }^{35}$ Kao uvijek u kriznim situacijama, potpuno transparentno pokazuju se odnosi moći u Uniji kao državnoj zajednici formalno ravnopravnih država, pod hegemonijom i vodstvom vodećih sila, Francuske i Njemačke.

Kriza je jasno razotkrila odnos vodećih sila prema, tijekom cijelog prošlog desetljeća teškom mukom dogovaranom i konačno izborenom "ustavnom ugovoru" iz 2009. godine, na kojem Unija formalno počiva nakon velike reforme započete još 2001. godine. Ugovor iz Lisabona mogli smo dobrim dijelom smatrati tacite suspendiranim u pogledu temeljnih propisanih putova i načina kreiranja političkih odluka već u trenutku kada je stupio na snagu ${ }^{36}$ Sljedeće godine njemačka kancelarka Angela Merkel predlaže ozbiljne promjene ustavnog ugovora kako bi se Unija mogla djelotvornije suočiti s krizom, posebno krizom eurozone, zatim se ubrzo predlaže (i) novi oblik udruživanja, bankovna unija, jer za ustavne promjene radi suprotstavljanja krizi nema vremena. Teoretičari europskog javnog prava, međutim, preferiraju ignorirati pokazatelje ustavne krize te preporučaju prionuti uz odluke Europskog suda bez pokušaja predviđanja daljnjeg razvoja. ${ }^{37}$

35 Istina, znanost je upozoravala na oprez, ali je ipak poraz Ustava na referendumima u Francuskoj i Nizozemskoj 2005. godine došao kao teški šok upravljačkoj eliti Unije. Smerdel, B., Temeljni problemi ustavnog izbora u Europskoj uniji: pokušaj preliminarne prosudbe rezultata Konvencije o budućnosti Europe, Zbornik Pravnog fakulteta u Zagrebu, vol. 53, br. 3-4, 2003., str. 509 - 527; Smerdel, B., European Union: the continuing process of constitutional choice, WOW Conference, Bloomington, Indiana, June 2006, dostupno na: https://www.pravo.unizg.hr/_download/repository/EUROPEAN_UNION_THE_CONTINUING_PROCESS.doc(1. prosinca 2018.).

36 Na to je više puta početkom 2012. godine upozoravao tadašnji predsjednik Europskog parlamenta Martin Schulz, kasnije neuspješni kandidat za predsjednika Komisije.

37 Smerdel, B., Constitutional Identity: Beyond the View From the Constitutional Courts, VIII. Congress of Constitutional and European Law, Sveučilište Regensburg, Njemačka, 22. 3. 2012., dostupno na: https://www.pravo.unizg.hr/_download/repository/Constitutional_identity.doc (1. prosinca 2018.). 
Na ustavnopravnom području to se novo stanje već krajem prvog desetljeća odražava kao zaoštravanje krize konstitucionalizma u pojedinim državama Europske unije, kao i na razini ustavnougovornog poretka same Unije te, u posebno ozbiljnom obliku, u Republici Hrvatskoj. Iz boce je pušten zao duh koji, kružeći Europom i svijetom, djeluje upravo suprotno od onoga što ga je prije 28 godina spominjao Bruce Ackerman. Šire se neliberalne demokracije, dapače, kako primjećuju utjecajni autori Ivan Krastev i Stephen Holmes, treba se bojati kako imitatori zapadnih demokracija iz 90-ih, suprotno od očekivanja, postaju model kojima se one okreću. ${ }^{38}$

Od nastojanja ka povezivanju, izraženog parolom “ever closer Union”, zahtjevi se okreću ka “never closer Union” kao formuli za spašavanje europskog jedinstva. ${ }^{39}$ Od tendencije dominacije sudstva skrenulo se ka bankovnoj uniji, u kojoj vrhovnu integracijsku silu čini nadzor Europske banke nad proračunima država članica. ${ }^{40}$ Novi oblik sukoba u okviru dvostruke ustavnosti jest situacija u kojoj nacionalni ustavni sudovi, štiteći socijalna prava zajamčena ustavima svojih država, stvaraju prepreke politici štednje koja, kao uvjet nužne ovlasti na području gospodarske politike, vodi ozbiljnim sukobima između izvršne vlasti i ustavnog sudstva, kao u Portugalu od početka europske pomoći 2012. godine. ${ }^{41}$ Financijske standarde posljednjih nekoliko godina uporno krši i Italija, odbijajući sugestije Komisije u nadzoru nad državnim proračunom, što je dovelo do izravne intervencije Europske komisije u studenome i upozorenjem Vijeća ministara s prijetnjom kaznenim mjerama 2018. godine. ${ }^{42}$

Učestali su slučajevi sustavnog kršenja načela konstitucionalizma, posebno akcijama izvršne vlasti protiv nezavisnosti pravosuđa i ustavnog sudstva u nizu zemalja "nove demokracije", poput Moldavije, Bjelorusije i drugih, što je bilo predmetom razmatranja Venecijanske komisije Vijeća Europe. Ali slična vrsta sukoba s ustavnim sudstvom javlja se i u novim članicama Europske unije, i to

38 Krastev, K.; Holmes, S., Explaining Eastern Europe: Imitation and Its Discontents, Journal of Democracy, vol. 29, br. 3, 2018., str. 117 - 128.

Scicluna, N., European Union: Constitutionalism in Crisis, Routledge, 2015., str. 17 - 49.

Quaglia, L., Central Banking Governance in the European Union: A Comparative Analysis, Routledge, Uaces Contemporary European Studies, 2008.

41 Primjerice tako 2012.: Portugalski Ustavni sud, kresanje 13. plaće i božićnice radnicima, www.index.hr/.../portugalski-ustavni-sud...neustavnima/624315.asp. Isto 2014.: Portugalski Ustavni sud ponovno srušio vladin plan ušteda, www.index.hr/ clanak.aspx?id=750669. (1. prosinca 2018.).

42 Europska komisija prijeti kaznenim mjerama: ministri..., https://net.hr/.../europska-komisija-prijeti-kaznenim-mjerama-ministri financija pozvali Italiju da poštuje propise Europske unije (4. prosinca 2018.). 
upravo onima u kojima su ustavni sudovi bili najjači: u Poljskoj, gdje je Ustavni tribunal uspostavljen, s velikim nadanjima reformista još 1986. godine, tako da je institucija imala očuvanu tradiciju ${ }^{43}$, te Mađarskoj, gdje je vrlo aktivni Ustavni sud 90-ih godina 20. stoljeća istican kao uzor novim demokracijama. ${ }^{44}$ Ovdje je vrijedno naglasiti kako je u oba slučaja u pitanju podvrgavanje sudaca volji vladajuće stranke te da je udar na ustavni sud obično prvi korak u uspostavljanju autoritarne vlasti. ${ }^{45}$

Pozornost Europske komisije su konačno privukla nastojanja putem umirovljenja sudaca Ustavnog suda po sili zakona u Mađarskoj 2012.46 Nakon povratka konzervativaca na vlast u Poljskoj vladajući su donijeli zakon koji je omogućio parlamentu smjenjivanje sudaca, uz pokušaj ultimativnog djelovanja Komisije, koji je u tijeku. ${ }^{47}$ Djelovanje tijela Europske unije na zaštiti temeljnih europskih ustavnih načela upućuje na njezine izrazite slabosti. U okolnostima nesigurnosti što ih je stvorio Brexit otvaraju se pitanja samog održanja Unije. ${ }^{48}$

Konstitucionalizam je, kao sastavni dio koncepta liberalne demokracije, konstatiraju najistaknutiji svjetski konstitucionalisti, u općoj i vrlo opasnoj

43 Tako da se u literaturi o demokratskoj tranziciji često navodi kao prvi u socijalističkim državama, dok je u Hrvatskoj, promicanjem fikcije potpunog diskontinuiteta, bilo potpuno zanemareno da je Ustavni sud SR Hrvatske djelovao od 1964. godine te odigrao iznimno važnu ulogu u uspostavljanju političkog pluralizma i demokracije, a predsjednici Jadranko Crnić i sudac Nikola Filipović bili su važni članovi novog sastava. Tek nakon naših upozorenja, poslije groteskne velike proslave petnaeste godišnjice djelovanja 2006. godine, na internetskoj stranici USUD.hr to je ispravljeno.

44 Smerdel, B., Nove demokracije, konstitucionalizam i organizacija vlasti, Zakonitost, vol. 47, br. 1, 1993., str. $5-22$.

45 Na primjer, Slobodan Milošević je odmah po dolasku na vlast došao u sukob s ustavnim sucima. Znakovita je njegova rečenica: "Ako ustavne suce štiti Ustav, ništa ih ne štiti od partijske odgovornosti." Godine raspleta, 1985., koju valja imati na pameti u svjetlu temeljnih postavki ustavne teorije i suvremene prakse.

46 Scheppele, K. L., How to Evade the Constitution: The Case of the Hungarian Constitutional Court's Decision on the Judicial Retirement Age, ComparativeConstitutions.com, 08 Aug 2012 (1. prosinca 2018.).

47 Dakako, svaki od njih zaslužuje poseban case study. Ovdje valja upozoriti na to kako akcija sankcijama protiv Mađarske nije uspjela, zbog protivljenja Češke i Poljske, dok Poljska početkom prosinca provodi mjere vraćanja na položaje smijenjenih ustavnih sudaca.

48 Can Europe be saved? - Europe at 60, The Economist, 25. 03. 2017., dostupno na: https://www.economist.com/leaders/2017/03/25/can-europe-be-saved (1. prosinca 2018.). 
krizi. ${ }^{49}$ Ponovno, kao i u pogledu predviđanja iznenadnog nastupa "kraja povijesti”, pokazuju se ograničene mogućnosti ranog prepoznavanja indicija u cilju sistemskih zaključaka. Međutim, uzimajući u obzir tu spoznaju, mislimo kako moramo pažljivo ocijeniti aktualnu situaciju, ocijeniti alternative i ostati na crti obrane demokracije u granicama ustavnog prava, kao najvišeg dosega evolucije na području ustrojstva "pristojne vlasti, kao jedinog mogućeg oblika 'dobre vladavine". 50

\section{USTAVNA KRIZA U HRVATSKOJ U OKVIRU OPĆE KRIZE KONSTITUCIONALIZMA}

Sve se to odvija u uvjetima dugotrajne, kronične krize ustavnosti u Republici Hrvatskoj, koja traje protivno našim optimističnim očekivanjima trijumfa konstitucionalizma nakon uspostavljanja mira i suvereniteta na cijelom teritoriju države. ${ }^{51}$ Međutim, u novije vrijeme postaje sve jasnije kako je prilika koju smo 2000. godine nazvali "hrvatska ustavna šansa" 52 , u smislu ubrzanog uspostavljanja stabiliziranog i djelotvornog institucionalnog sustava vladavine prava, propuštena, a razlozi za to velikim su dijelom objektivne naravi. Ustavnom krizom smatramo, na prvom mjestu, stanje u kojemu se pomoću uobičajenog razumijevanja ustavnih normi ne može razriješiti neka ozbiljnija konfliktna situacija, obično između nositelja vlasti u državi. ${ }^{53}$

49 Graber, M. A.; Levinson, S.; Tushnet, M. (ur.), Constitutional Democracy in Crisis?, Oxford University Press, 2018., str. 5 - 18.

50 Usporedi naš komentar povodom Bijele knjige Europske komisije o načelima "dobre vladavine” (good governance) u: Smerdel, B., Ustavno uređenje europske Hrvatske, Narodne novine, Zagreb, 2013., str. 50 - 55.

51 Smerdel, B., Akutna kriza vlasti izraz je kronične krize hrvatskog konstitucionalizma, Hrvatska pravna revija, vol. 17, br. 6, 2017., str. 1 - 13.

52 Ova kovanica, kojom smo željeli upozoriti na krucijalnu važnost institucionalizacije i stabilizacije pravnog sustava kao uvjeta napretka, dočekana je u medijima i političkim strankama s mnogo nerazumijevanja i zbog toga čak i poruge: "Za tako nešto nije se do tada čulo!”. U pitanju je, međutim, ono na što su nas cijelo vrijeme "nadzirane tranzicije", od kandidature za prijam u Vijeće Europe 1996. godine, tijekom pregovora, pa sve do punopravnog članstva u Europskoj uniji, upozoravali savjetnici iz "međunarodne zajednice", inzistirajući na reformi pravosuđa i uprave. Tužno je kazati kako se problemi još produbljuju godinama nakon stupanja u članstvo. Vidi Smerdel, Konstitucionalizam i promjena vlasti, op. cit. u bilj. 16.

Smerdel, B., op. cit. u bilj. 51. 
Za razliku od toga, u Hrvatskoj govorimo o općoj i kroničnoj krizi konstitucionalizma, koja se sastoji od nepostojanja temelja za funkcioniranje usvojenih i važećih ustavnih institucija i institucionalnih sklopova (rules on the book) koji ne mogu djelovati, ni zaživjeti kao working rules izvan dosegnutog minimalnog stupnja pravne odnosno ustavne kulture, to jest internalizirane svijesti o nužnosti poštivanja ustava i prava, koja se u rimskom pravu naziva opinio juris sive necesitatis. Hrvatska politička klasa tradicionalno smatra ustave i zakone pogodnim sredstvima u političkoj borbi, a inače ih je sklona ignorirati. ${ }^{54}$ Široki slojevi građanstva ne očekuju da bi im ustavne norme, odnosno sustav konstitucionalizma, mogao omogućiti zadovoljavanje njihovih pojedinačnih i grupnih interesa ili opći boljitak. ${ }^{55}$

U Hrvatskoj se pravnoj teoriji ta pitanja još pretežito ignoriraju te se uporno upozorava na neostvarene, ali nikako neostvarive ciljeve europskih integracija, kao i na desetljećima stare sudske odluke.

Pravna teorija povukla se dobrim dijelom pred izazovima u područje "čistog normativizma", odbijajući se suočiti s preobiljem dokaznog materijala o neprovođenju novih, reformskih zakona. To se lijepo uklopilo u tradiciju iz doba ideološke diktature, po kojoj se novi zakoni u pravilu hvale kao bolji od prijašnjih, a neki od njih i kao "najbolji u Europi", bez obzira na primjenu i bez obzira na činjenicu što nikada ni neće biti primijenjeni. Odluke ustavnih i europskih sudova uzimaju se kao pravo i konačno stanje stvari (curia locuta, causa finita). Tako se uporno inzistira na odlukama Europskog suda, koje su prema tom tumačenju 60-ih godina prošlog stoljeća uspostavile načelo potpune supremacije svih izvora europskog prava nad domaćim zakonodavstvom i nad ustavima zemalja članica Unije, citirajući odluke Van Gend en Loos iz 1963. i Costa vs. Enel iz 1964. godine te nekoliko drugih koje utvrđuju supremaciju europskog nad nacionalnim zakonodavstvom. ${ }^{56}$

54 Dobar primjer je odnos svih dosadašnjih vlada prema problemu rješavanja sukoba interesa, koji traje sve od prve zakonodavne inicijative iz 1997. godine u obliku nerazumijevanja u političkoj kulturi u kojoj se, kako se u Saboru izrazio zastupnik Budiša, politika smatra prilikom za pomaganje sebi i drugima, a nastoji isključiti svaka odgovornost. Smerdel, B., O neustavnosti Zakona o sprečavanju sukoba interesa, Informator, vol. 59, br. 5977, 2011., str. 1 - 32. Posebno važan primjer je način izbora sudaca Ustavnog suda, obavljen 2016. godine. Smerdel, B., Kako na ustavan način izabrati suce Ustavnog suda, Hrvatska pravna revija, vol. 16, br. 3, 2016., str. 5 - 10.

55 Berend, T. I., Europe in crisis: bolt from the blue?, Routledge, 2013.; Kube, H., The EU Financial Crisis - European Law and Constitutional Law Implications, Mario Einaudi Center for International Studies, Cornell University, 2012.; Commission for Human Rights, Council of Europe, 2014, Safeguarding human rights in times of economic crisis, https://rm.coe.int/09000016806daa3f (1. prosinca 2018.).

56 Ćapeta, T.; Rodin, S., Osnove prava Europske unije, 2. izdanje, Narodne novine, 2011., str. $62-63$. 
Upozorenja kako je riječ o dinamičnoj zajednici država te kako za znanstveni uvid u stanje i perspektive razvoja Unije moramo pokušati sagledati proces implementacije, jednostavno steći uvid u ono što se događa nakon što sudovi donesu odluku, nerado se i s negodovanjem prihvaćaju od pravnika koji traže sigurnost čvrsto se držeći doktrine o ekstrajuridičkim elementima, a ignorirajući doktrinu stare decisis. ${ }^{57}$

Još 2014. godine, kada je kriza upravljanja Unijom poprimila vrlo ozbiljne razmjere, Direktorat Europske komisije proveo je, pod vodstvom Leonarda Besselinka, istraživanje o stupnju recepcije potpune supremacije europskog prava nad nacionalnim pravima, što bi imalo uključivati i ustavne norme. Hrvatski profesori europskog javnog prava upozorili su kako, u sveopćem suglasju, ima i onih koji upućuju na mogućnost sukoba oko neprenesenih ovlasti. ${ }^{58}$

\section{OD SVEČANOG PROGLAŠENJA, DO SVAKODNEVNOG PODCJENJIVANJA USTAVA}

U prvo vrijeme nakon stjecanja međunarodnog priznanja i uspostavljanja suverene Republike Hrvatske velike su se nade polagale u novi Ustav kao okvir i sredstvo borbe za demokraciju. Simbolički, kada je dr. Franjo Tuđman,

57 Smerdel, B., Beyond the Decisions of the Courts, paper presented at the international conference European Constitutionalism in the Decisions of the Courts, Regensburg, Germany, March 20, 2011.

58 Tamara Ćapeta: "Some authors have taken a different position. Professor Smerdel, for instance, argues that it would not be wise to give complete supremacy to EU law and to give up on the Croatian Constitution. The claim for 'reserved constitutional domain' should not only be made by larger EU Member States such as Germany and France, but also by smaller ones which are smaller but still equal. On the basis of the doctrine of constitutional identity, constitutional courts may decide to give supremacy to national constitutions over EU law. In order to support this argument, Professor Smerdel makes explicit reference to the case law of the German Constitutional Court as well as to other constitutional courts which have developed the theory of constitutional identity. This theory was the fundamental basis for decisions of those courts in which primacy is given to national constitutional law. As for Croatia, there are no provisions in the Croatian Constitution precluding the Constitutional Court from adopting the same approach, according to Smerdel. It is in fact fairly easy to construe a constitutional basis for the supremacy of national constitutional law over EU law in relevant matters, even though it is not explicitly stated in the Constitution (Croatian negotiators in the accession process have warned that including such a provision in the Constitution would mean the end of negotiations)", European Commission, Directorate General for Internal Policies, 2014. 
polažući predsjedničku prisegu, na kraju dodao jednu rečenicu koja nije bila zapisana u zakonu, "Tako mi Bog pomogao", nastala je konsternacija. Predsjedniku Crniću stručna je javnost predbacivala kako je trebao intervenirati i time postaviti značajan presedan. ${ }^{59}$ Zakon je izmijenjen! Kada je predsjednik Mesić objavio da on ne namjerava nositi državnu lentu, na upozorenje kako je na to obvezan po zakonu, samo je odmahnuo rukom. Zakon nije promijenjen! ${ }^{60}$ Kada je, pak, premijer Plenković tijekom 2017. godine opetovano izjavljivao kako ga se pozivanja na ustavna ograničenja od strane stručnjaka ne tiču, to je samo pridonijelo sveopćoj šutnji u pogledu učestalog ignoriranja Ustava od strane njegovih ministara. ${ }^{61}$

Jedan od nekoliko Plenkovićevih prethodnika, premijer Zoran Milanović, u više je prilika javno podcjenjivao Ustav, prijetio raspuštanjem Ustavnog suda, ignorirao dignitet institucije šefa države itd. Hrvatska udruga za ustavno pravo, jedanaest sveučilišnih nastavnika ustavnog prava, upozorilo je u lipnju 2013. godine otvorenim pismom premijera kako ne smije prijetiti zabranama pojedinih ovlasti koje građanima daje Ustav. Nakon toga, isto je javno upozorenje morao uputiti i Ustavni sud. Kada je 2018. godine gradonačelnik Rijeke Vojko Obersnel zabranio prikupljanje potpisa za referendum građanske inicijative na svojem području, osim nositelja inicijative Narod odlučuje, kojoj se iz stručnih i političkih razloga odlučno protivim, jedino sam ga ja osobno, kao učitelj ustavnog prava, u medijima upozoravao kako je riječ o primjeni Ustava, što je daleko iznad dosega njegova položaja. Jednog dugogodišnjeg zastupnika nacionalnih manjina takva je moja intervencija dovela do izljeva bijesa na Hrvatskoj televiziji i ponovno upozorila na dječju bolest hrvatskog konstitucionalizma: ustavnim smatramo samo ono što nama odgovara. Spremni smo uništiti svakoga tko nas upozorava na ustavna ograničenja našeg položaja. Posebno groteskno je kada takav napad na sam Ustav dolazi od zastupnika nacionalne manjine, čijih je posebnih prava Ustav i jamstvo i jedini izvor i oslonac.

59 Mudri predsjednik Ustavnog suda, još iz starog režima, ponovno imenovan 1991., znao je kako bi to bilo krajnje neprimjereno svečanoj prilici predsjedničke prisege, i to još prvoj u suverenoj Hrvatskoj. Ali nije mogao prikriti nezadovoljstvo onime što se dogodilo.

60 Čl. 26. Zakona o grbu, zastavi i himni Republike Hrvatske te zastavi i lenti predsjednika Republike Hrvatske, Narodne novine, br. 55/1990, 26/1993 i 29/1994. Uz to, predsjednik Mesić nosio je lentu, pokoravajući se protokolu velikog vojvode luksemburškog u prigodi državnog posjeta. Možemo govoriti o sitnicama koje su postupno ruinirale Ustav.

${ }_{61}$ Vijest od 11. 5. 2017., www.indeks.hr/clanak/plenković se bahati/969431.aspx. (1. prosinca 2018.). 
Razvoj konstitucionalizma u slobodnoj, suverenoj i demokratskoj Republici Hrvatskoj ne odvija se u skladu s dominantnim predviđanjima društvenih znanosti. Još tijekom borbe za međunarodno priznanje suverenosti i samostalnosti unutar dominantnog HDZ-a formirale su se suprotstavljene skupine "tehnokrata" i "suverenista", koje je uspješno balansirao predsjednik Republike Franjo Tuđman svojim neprijepornim autoritetom oca domovine. Ti sukobi rasplamsali su se nakon Tuđmanove smrti, ali u stranci u opoziciji nisu bili toliko opasni za samu državu. Činilo se kako nisu važni ni za drugu veliku stranku, SDP, koju je neznalačko ali autoritativno vodstvo Zorana Milanovića tijekom desetak godina, uključujući brojne izgubljene izbore, ali i pet godina na vlasti, dovelo do gotovo potpune propasti. Dapače, prešutni konsenzus oko zajedničkog djelovanja dviju, sve više dezideologiziranih catch all stranaka na ispunjavanju uvjeta za punopravno članstvo u Europskoj uniji davao je prividno velike šanse za primjenu ustavotvornog inženjerstva u izgradnji demokratskih institucija. ${ }^{62}$

Dakako, priznavali smo i nastojali znanstvenim krugovima na zapadu pojasniti kako su okolnosti oružane agresije na državu, uz izvana potaknutu oružanu pobunu dijela stanovništva te okupaciju trećine državnog teritorija, nametnule prioritete kakve zahtijevaju takve situacije u kojima je ciljevima obrane od agresije podređen cijeli pravni sustav te koje neizbježno vode koncentraciji vlasti u rukama državnog poglavara. ${ }^{63}$ Borba za ustavnost potaknuta je nakon pobjede u ratu, pod nadzorom i diktatom ("monitoring” je ušao u hrvatski jezik) međunarodnih organizacija, odnosno, kako je u jednom članku u International Herald Tribuneu duhovito napomenuo prvi visoki predstavnik međunarodne zajednice u Bosni i Hercegovini Wolfgang Petrich, “ispravnije rečeno - velikih sila”, već polovicom devedesetih godina prošlog stoljeća, a posebno nakon kandidature za članstvo u Vijeću Europe.

Promjena stranaka na vlasti i obećanja šesteročlane "Koalicije za politiku novog smjera" 2000. godine ${ }^{64}$ te ustavne promjene čiji je glavni cilj bilo postav-

62 Smerdel, B.; Gardašević, Đ. (ur.)., Izgradnja demokratskih ustavnopravnih institucija Republike Hrvatske u razvojnoj perspektivi - izabrani radovi projekta MZOŠ broj 0660661428-2502 (2007.-2011.), Hrvatska udruga za ustavno pravo, 2011.

63 Smerdel, B., Republic of Croatia: Three Fundamental Constitutional Choices, presented at the Conference on Constitutionalism in Eastern and Middle Europe, held at the Chicago University School of Law, October 18-21, 1991; Smerdel, B.: Croatian Imperial Presidency, Budapest, 1993.; oba izlaganja dostupna su na: https://www.pravo. unizg.hr/_download/repository/Early_years_of_Croatian_independence_-_collection_of_papers_-_legal_foundations_-_fundamental_constitutional_choices_-_political_system.doc (1. prosinca 2018.).

64 Smerdel, Konstitucionalizam i promjena vlasti, op. cit. u bilj. 16, str. 1 - 2, 5 - 20. 
ljanje normativnih prepreka koncentraciji vlasti, dala je krila novim nastojanjima konstitucionalista. ${ }^{65}$

Napori na izgradnji ustavnih institucija, jačanju sustava vladavine prava i promicanju zaštite ljudskih sloboda i prava razotkrili su svu silu neočekivanih problema i nerazumijevanja znanosti o ustavnoj arhitekturi i ustavnom inženjerstvu. Jedna iznimno teška pogreška u tom pogledu učinjena je uvođenjem proporcionalnog predstavništva $\mathrm{u}$ jedinicama lokalne samouprave. ${ }^{66}$ Druga velika pogreška, zaista fatalna za stabilizaciju ustavnog sustava, bila je odluka da se već sljedeće godine nakon velike ustavne reforme iz 2000. godine Ustav ponovno promijeni 2001. godine, u velikoj mjeri u pravcu suprotnom ranijoj reformi, primjerice ukidanjem Županijskog doma, koji je godinu dana prije bio čak ojačan. Zbog toga smo predviđali daljnje ustavne promjene, uzdajući se kako će, uz sugestije međunarodne zajednice, prevladati stručni pristup ustavnim pitanjima. ${ }^{67}$

Međutim, ideja kako se otvorenim procesima može upravljati iz političkog centra preživjela je i skori odlazak koalicije lijevog centra s vlasti ${ }^{68}$ te se uporno održavala i dalje, kada je već postalo jasno kako smetnje u hrvatskoj naslijeđenoj političkoj kulturi ozbiljno ometaju napredak, a očekivana i obećavana pomoć u procesu "ubrzane tranzicije" izostaje ili se svodi na diktiranje propisa, bez ozbiljnog uvida u mogućnosti njihove provedbe. Potisnuta je svijest o važnosti i prilikama koje otvaraju ustavna jamstva. ${ }^{69}$ Cinična, godinama ponavljana izreka kako institucije trebaju raditi svoj posao popraćena je sveopćom apatijom i pasivnošću većine građana. $^{70}$

65 Radna skupina predsjednika Republike: Mratović, V.; Smerdel, B.; Bačić, A.; Crnić, J.; Filipović, N.; Lauc, Z., Stručne osnove mogućeg prijedloga ustavnih promjena, Zbornik Pravnog fakulteta u Zagrebu, vol. 50, br. 3, 2000., str. 374 - 375 (prijevod na engleski jezik pripremio Smerdel, B., str. 451 - 473).

66 Smerdel, B., Konstitucionalizam i stabilnost ustava u: Europske perspektive demokratske Hrvatske, Hans Seidel Stiftung, 2001., str. 93 - 101.

67 Smerdel, B., Hrvatski pravni sustav i ustavno načelo vladavine prava, Zbornik Pravnog fakulteta u Zagrebu, vol. 51, br. 6, 2001., str. 1149 - 1162.

68 Kregar, J.; Ravlić, S.; Puljiz, V. (ur.), Hrvatska: kako dalje - zadanosti i mogućnosti, Pravni fakultet Sveučilišta u Zagrebu, Centar za demokraciju i pravo "Miko Tripalo", 2004.; Ravlić, S.; Kregar, J.; Flego, G. (ur.), Hrvatska: Kako sada dalje?, Pravni fakultet Sveučilišta u Zagrebu, Centar za demokraciju i pravo "Miko Tripalo", 2008.

69 Usporedi https://www.slobodnadalmacija.hr/novosti/hrvatska/clanak/id/301840/ akademik-davorin-rudolf-upozorava-bez-ustavnog-suda-hrvatska-se-vraca-150-godina-unatrag (1. prosinca 2018.).

70 Vidi Zašto neposlušne institucije ne rade svoj posao u: Smerdel, B., O ustavima i ljudima, Informator, 2012. Predmet sprdnje cjelokupne javnosti, floskula se ponavlja do da- 


\section{SUKOB HRVATSKE VLADE S EUROPSKOM KOMISIJOM}

Nakon ulaska RH u punopravno članstvo EU-a nastupile su signifikantne promjene u općem odnosu prema Ustavu i ustavnosti, trajno obilježene lošim početkom i pokvarenom proslavom te onim što je od ključnog značenja: principijelnim ustavnokonvencijskim sporom s Europskom komisijom, napose s povjerenicom za sudstvo i ljudska prava Vivianne Reading. U pitanju je nespretni pokušaj Milanovićeve vlade da pomoću zakonskih promjena izuzme dvojicu optuženih visoko rangiranih hrvatskih obavještajaca, ranijih pripadnika jugoslavenske tajne policije, od primjene europskog uhidbenog naloga nekoliko dana prije svečanosti stupanja u punopravno članstvo Europske unije, a zatim otvaranje ustavnih promjena sa svrhom da se sanira izazvana kriza, koji je $\mathrm{u}$ prosincu 2013. godine bio pred usvajanjem.

Spor je uzrokovan pogrešnim pristupom hrvatske Vlade, ustrajavanjem na rješenjima takozvanog lex Perković u pogledu primjene europskog uhidbenog naloga. ${ }^{71} \mathrm{Na}$ unutarnjem planu Vlada je izlaz potražila u paketu ovlaš dogovorenih i sa stručnog stajališta apsolutno neprihvatljivih ustavnih promjena. Predsjednik Republike Josipović, očito nastojeći očuvati svoj ugled profesora prava, a istodobno izbjeći sukob s premijerom Milanovićem, poslao je primjedbe na taj očajno nestručan nacrt ustavnih promjena, ali s teško objašnjivim zakašnjenjem. Takvo groteskno tumačenje zaista nas je ogorčilo, pa i danas smatramo kako nije zasluživalo bolji komentar: "Zakasnio je na javnu raspravu i, kaže gospodin Grbin, nema pravo sudjelovati. Pa molim vas lijepo! Svaki seljak znade da kum nije dugme, a predsjednik Hrvatske bogme nije isti kao svi ostali građani. On je ovlašteni predlagatelj ustavnih promjena kojeg je izabrala većina birača. To je jedan pokazatelj stanja ustavnosti koje je vrlo zabrinjavajuće". Pokazan je potpun nemar ili nerazumijevanje smisla i svrhe nadzakonske pravne snage ustavnih normi.

Novinar izvješćuje: "Smerdelu je problematičan dio u kojem se navodi da Sabor može, većinom glasova svih zastupnika, odlučiti da se i drugi zakon donese po postupku određenom za promjenu Ustava. On tvrdi: 'Ustavotvorac treba

našnjeg dana. Vidi pjesmu grupe Hladno pivo "Neka institucije rade svoj posao" iz 2009. godine na http://www.urbancult.hr/276l.aspx. Ali vidi i komentar Bože Kovačevića iz listopada 2018. godine na https:/www.telegram.hr/price/danima-slusamo-hdz-i-frazu-neka-institucije-rade-svoj-posao-smijesno-kao-da-oni-nisu-krivi-za-njihovo-nefunkcioniranje/ (1. prosinca 2018.).

71 Zakon o izmjenama i dopunama Zakona o pravosudnoj suradnji u kaznenim stvarima s državama članicama Europske unije, Narodne novine, br. 91/2010, 81/2013, 124/2013, 26/2015, 102/2017, 68/2018. 
odrediti tko donosi zakone i na koji način, ako onaj koji donosi zakone to sam odlučuje, to je onda protivno načelima ustavnosti i rušenje Ustava. Upozoravam da se to ne bi smjelo dopustiti, a vidjet ćemo da se na dugi rok sve plaća..' ${ }^{72}$ Kao član Odbora za Ustav, Poslovnik i politički sustav iz reda znanstvenih radnika nisam mogao ne reagirati, ali sam ostao potpuno usamljen, na zajedničkoj sjednici tog Odbora s Odborom za zakonodavstvo na kojem je, u odsutnosti glavne oporbene stranke, trebalo usvojiti dogovoreni nestručni projekt. Odbor je to disciplinirano i učinio, ali očekivano usvajanje dvotrećinskom većinom u plenumu ipak se nije dogodilo jer je Hrvatski demokratski savez Slavonije i Baranje, manji koalicijski partner, u posljednji tren obznanio da neće podržati tako vremenski isforsirane izmjene Ustava. Pozvan da taj potez javno komentiram, rekao sam: "Na sjednici Odbora za Ustav pozvao sam sve da još jednom razmisle i ne lome ustavne promjene preko koljena. Neke bitne stvari nisu regulirane. Neke su očito namjerno propuštene. Zastupnik Lesar veli, dogovorili smo ulogu Ustavnog suda, ali nismo napisali. Pa zašto niste? Rekao sam na TV-u da sam odglumio glas vapijućeg u pustinji. Nitko nije reagirao. Ljudi koji bi trebali znati bolje jednoglasno su glasovali po direktivi. Dakle, odluku HDSSB-a mogu samo pozdraviti. Uostalom, to je bit demokratske ustavne teorije čiji razvoj pratim i koju predajem već četiri desetljeća." ${ }^{33}$

\section{USTAVNI OPTIMIZAM: JE LI MOGUĆ POVRATAK KONSTITUCIONALIZMU?}

Ustavni optimizam uvijek se ponovno javlja tijekom povijesti kao izraz nade čovječanstva da bi moglo doći vrijeme kada neće, riječima američkih utemeljitelja, "ovisiti o slučajnosti i nasilju", da bi ga slijedio pesimizam kao posljedica neostvarenih ekstenzivnih očekivanja.

Već smo citirali konstataciju razočaranog Karla Loewensteina kako "Ustav nije uspio u onome što se od njega najviše očekivalo: uspostaviti društveni poredak siguran od šokova i kriza", nota bene, iz 1957. godine. Kao i taj oduševljeni pristaša konstitucionalizma, jedan od onih znanstvenika koji su na vrijeme predvidjeli nadolazeću katastrofu demokracije u Njemačkoj i koji su se za dobrodošlicu i azil Sjedinjenim Američkim Državama izdašno odužili svojim fundamentalnim prilozima američkoj političkoj znanosti, možemo i mi danas

72 https://www.24sata.hr/news/odbor-ce-pripremiti-konacan-prijedlog-ustavnih-promjena-345532 (1. prosinca 2018.).

73 http://www.republika.eu/novost/21263/pozdravljam-potez-hdssb-a-sto-su-postupili-prema-svojoj-savjesti-jer-ustav-se-ne-lomi-preko-koljena (1. prosinca 2018.). 
konstatirati sljedeće: “Teško je vjerovati da ustav znači bilo što, i bilo gdje, za malog čovjeka stiješnjenoga između čekića i nakovnja. On je indiferentan prema 'svom' ustavu, jer je ustav indiferentan prema njemu. Mase naroda su dovoljno prosvijetljene da bi se smatrale ovlaštenima zahtijevati osnovnu društvenu pravdu i ekonomsku sigurnost. Ali i najljepše napisan ustav ne može zadovoljiti te želje, baš kao niti pretenciozni zakoni o društveno-ekonomskim pravima. Ustav ne može premostiti jaz između siromaštva i bogatstva. On ne može osigurati hranu, stan, odjeću, obrazovanje i rekreaciju - osnovne životne potrebe. Svugdje su društva-države neizbježno usmjerene prema državi blagostanja. Osim toga, bit pisanih ustava postala je stagnantna. O životnim pitanjima, koja utječu na svakodnevni život ljudi, više ne odlučuju ustavno uspostavljena tijela, već grupe za pritisak i političke stranke, koje ustavi najčešće ignoriraju, i koje najčešće djeluju izvan njihova sklopa.

Takav nehaj, ako ne i neprijateljstvo, masa ljudi prema "njihovim" ustavima izgleda opravdana: ono što ustavi iskazuju kroz svoje složene i razrađene podrobnosti - igra između nositelja vlasti - ne tiče se običnog čovjeka; ono što upravo zanemaruju, jesu bitne potrebe njegove svakodnevne egzistencije. Propagandne ideološke postavke za njega su prazna obećanja. Ustav nije uspio u onome što se od njega najviše očekivalo; on nije uspio uspostaviti društveni poredak siguran od šokova i kriza."74

Ovaj često citirani odlomak pokazuje koliko su velika bila očekivanja znanstvenika nakon pobjede demokratskih država i njihovih saveznika u svjetskom ratu protiv nacističkih, fašističkih i militarističkih autokracija i ponovnog uspostavljanja liberalnog konstitucionalizma kao temeljnog načela organizacije vlasti u jednom dijelu antifašističke koalicije, predvođenom Sjedinjenim Američkim Državama. Dakako da su takva očekivanja bila osuđena na propast u obnovljenom svijetu utemeljenom na prijetećem ratnom sukobu suprotstavljenih blokova i naoružanih ideologija.

Pa ipak, ustavni optimizam, u gotovo euforičnom obliku, ponovno je prevladao početkom 21. stoljeća u vrijeme priprema za donošenje "Ustava Europe". Peter Häberle navodi brojne takve razloge koji zahtijevaju reformu ustavne države, uz očuvanje temeljnih načela konstitucionalizma i vladavine prava, koji su gotovo univerzalne važnosti jer se javljaju u gotovo svim modernim državama. Oni obuhvaćaju sljedeći popis: smanjivanje masovne nezaposlenosti, mirovinska reforma, zaduženost zemlje, zaštita okoliša, smanjivanje državne birokracije ("mršava država”), borba protiv organiziranog kriminala i korupcije,

74 Loewenstein, K., Political Power and Governmental Process, University of Chicago Press, 1957., str. 160 - 161. 
pluralistički nadzor nad sredstvima masovnih komunikacija, odgovor na izazove novih tehnologija, kriza stranačke demokracije, zakonsko i etičko jačanje ideje o dužnostima, migracije te, danas posebno aktualno, izazovi islamskog fundamentalizma, izazovi su koji prijete očuvanju demokratskih poredaka i vladavine prava. ${ }^{75}$ Dakako, takva su shvaćanja uglednih europskih pisaca samo ojačala ukorijenjeni hrvatski normativni optimizam kao uvjerenje da se problemi rješavaju pisanjem (ili prepisivanjem) novih propisa. ${ }^{76}$

\section{ZAKLJUČAK: DEMOKRATSKI KONSTITUCIONALIZAM NEMA ALTERNATIVE}

Mudrost demokracije očituje se u tome što je ona kao život, nesavršena, puna nesigurnosti, pa zbog toga dopušta odgodu, promišljanje, preispitivanje. U ovom slučaju, nužno i zakonom propisano nastojanje da se unaprijed procijeni učinak propisa. Suvremenim jezikom kazano, razborito odlučivanje zahtijeva cost-benefit analizu, procjenu učinaka i troškova prije poduzimanja zakonskih mjera, posebno onih prisilnih. Taj se zahtjev tiče svih propisa, ali na prvom mjestu samoga Ustava, koji ne smije biti sredstvo političkih nadmudrivanja.

Nedovršeni Brijunski plan ustavnih promjena predsjednika Josipovića utemeljen je na realističnoj ocjeni situacije i bio je usmjeren na bitne promjene tijekom planiranog drugog njegova predsjedničkog mandata. Gubitkom predsjedničkih izbora plan provedbe ustavnih promjena potisnut je u drugi plan, ali ostaje kao stručna analiza stanja od koje će morati poći svaka buduća vlada, odnosno parlamentarna većina. ${ }^{77}$ Ova pitanja, koja smatramo krucijalno važnim za očuvanje demokracije i razvoj hrvatskog političkog sustava, morat će biti, prije ili kasnije, planirana kao projekt jedne sveobuhvatne analize u svrhu pripreme nužnih ustavnih promjena.

Međutim, situacija je u tom pogledu danas mnogo teža nego nakon provale entuzijazma u Godini čuda, početkom posljednjeg desetljeća 20. stoljeća. Nakon otvaranja granica novih demokracija ideja postupne, koliko god poticane,

75 Häberle, P., The Constitutional State and Its Reform Requirements, Ratio Juris, vol. 13, br. 1, 2000. , str. 77 - 94; Häberle, P., Ustavna država, Politička kultura, 2002.

76 Smerdel, op. cit. u bilj. 67, str. 5 - 25.

77 Radna skupina predsjednika Republike radila je u sastavu: Arsen Bačić, Petar Bačić, Sanja Barić, Đorđe Gardašević, Zvonimir Lauc i Branko Smerdel. Aktivno je, kao vođa i član skupine, sudjelovao predsjednik Republike Ivo Josipović. Dokument, međutim, nije bio dovršen, ali ga je Josipović koristio kao važan element svoje predizborne kampanje. 
izgradnje novog institucionalnog sustava izgubila je na atraktivnosti. Umjesto ponovnog sudjelovanja u izgradnji "boljeg svijeta budućnosti” mladi ljudi pohrlili su u taj željeni i nestrpljivo očekivani svijet. Nakon velikog proširenja najprije se u zapadnu Europu preselilo više od milijun Poljaka. Slijedili su i drugi: između 1989. i 2017. iz Bugarske se na zapad iselilo 21 posto stanovništva, iz Latvije 27 posto, iz Litve 22,5 posto. Oko 3,4 milijuna ljudi, većinom mlađih od 35 godina, napustilo je Rumunjsku, a Hrvatsku do 2018. godine oko tristo tisuća. Narav tog trenda dobro pokazuje i podatak kako se, nakon ponovnog ujedinjenja, oko dva milijuna Nijemaca preselilo u raniju zapadnu državu. ${ }^{78}$ Depopulacija cijelih regija postala je središnje pitanje hrvatske strategije. Istodobno, jača pritisak tisuća migranata iz Afrike i Azije, pri čemu je Hrvatskoj ponovno dodijeljena uloga "predziđa", sada šengenske zone otvorenih granica.

Vincent Ostrom je, sumirajući rezultate svojih upornih studija i istraživanja, dramatičnim tonom konstatirao: "U pogledu upravljanja ljudskim društvima nismo mnogo napredovali od američkih utemeljitelja s kraja 18. stoljeća."79 Današnja kriza demokracije i konstitucionalizma u Europi i svijetu pokazuje kako je ovo upozorenje neumornog studenta-istraživača, koji je uporno plivao protiv matice, što se uobičajeno naziva communis opinio doctorum, a najčešće znači oportunizam, dobrim dijelom bilo i te kako potrebno. Jer, protivno očekivanjima, niti je ustavna revolucija i tranzicija postkomunističkih sustava, koja je uslijedila nakon što je Annus mirabilis, početkom posljednjeg desetljeća 20. stoljeća, donijela očekivani procvat, niti se širenje demokracije u svijetu od posljednje četvrtine tog stoljeća pokazalo ireverzibilnim procesom, prema očekivanjima većine teoretičara.

Zato Timothy Snyder četvrt stoljeća kasnije ponovno upozorava: "Možda bismo mogli pomisliti da nas demokratsko nasljeđe automatski štiti od takvih opasnosti. Ali to je pogrešan refleks... Današnji Amerikanci nisu nimalo mudriji od onih Europljana koji su u 20. stoljeću gledali kako demokracija uzmiče pred fašizmom, nacizmom i komunizmom. Naša je jedina prednost što možemo učiti iz njihova iskustva. I sada je pravi trenutak za to." 80

Posljednjih godina, međutim, jasno je da su promjene takve naravi da zahtijevaju potpuno novi teorijski pristup. Umjesto Häberleova društva slobodnih tumača Ustava, prijeteća propast ideje liberalne demokracije i konstitucionali-

78 Parafrazirajući naslov knjige Krasteva i Holmesa moglo bi se kazati kako je pobjeda nacionalizma dovela do opasnosti održanja nacija.

79 Ostrom, V., The Meaning of Democracy and the Vulnerabilities of Democracies, A Response to Tocqueville's Challenge, University of Michigan Press, 1997., str. $264-267$. 
zacije podsjeća nas alarmantno na tvrdnju uvjerenog optimista konstitucionalizma Karla Loewensteina: "Kada dođe njegovo vrijeme, novi Montesquieu će se pojaviti". ${ }^{81}$ Ali nove ideje i koncepti ne pojavljuju se, dapače, mnogi skreću pogled prema konceptima izbornih autokracija, u kombinaciji s paradoksalnim "modelima" autoritativne vlasti, od Mađarske do Venezuele. ${ }^{82} \mathrm{U}$ tom cilju i u Hrvatskoj poziva se "narod" na ulice, po uzoru na nasilni protest tisuća Parižana u studenom i prosincu 2018. Populizam prijeti uspostavljanjem autoritarne vlasti u velikom broju zemalja članica Europske unije. ${ }^{83}$ Bitno je pitanje je li u predstojećim sukobima ustavobranitelja i populista moguće očuvati temeljna načela i temeljne vrijednosti demokratskog konstitucionalizma i demokracije. “'Taking back constitutionalism' or 'make constitutionalism great again' may be the new motto." ${ }^{84}$

\section{LITERATURA}

Ackerman, B., The Future of Liberal Revolution, Yale University Press, 1992.

Ahdieh, R., Russia's Constitutional Revolution: Legal Consciousness and the Transition to Democracy, Pennsylvania State University Press, 1997.

Basta Fleiner, L.; Marinković, T. (ur.), Central European Democratic Transition. The Paradigm of Constitutional Revolution, Key Developments in Constitutionalism and Constitutional Law, Eleven International Publishing, 2014.

Berend, T. I., Europe in crisis: bolt from the blue?, Routledge, 2013.

Brzezinski, Z., The Choice. Global Domination or Global Leadership, Basic Books, 2004.

81 U: Zurcher, A. J., Constitutions and Constitutional Trends since WW II, New York University Press, 1951., str. 224, cit. Mratović, V. (ur.), Problemi suvremene države, Naprijed, 1971., str. 133.

82 Hernández G. J. I., Towards a Concept of Constitutional Authoritarianism: The Venezuelan Experience, Blog of the International Journal of Constitutional Law, Dec. 14, 2018, dostupno na: http://www.iconnectblog.com/2018/12/towards-a-concept-of-constitutional-authoritarianism-the-venezuelan-experience/ (1. prosinca 2018.).

83 Činjenica što se ti pozivi upućuju preko Facebooka i drugih društvenih mreža ni u kojem slučaju ne umanjuje njihovu važnost: u dobrom dijelu populacije to su glavni oblici informiranja.

84 Fichera, M., The Paradox of Liberal Constitutionalism: a Call for Communal Constitutionalism, VerfBlog, 11. 10. 2016., dostupno na: https://verfassungsblog.de/the-paradox-of-liberal-constitutionalism-a-call-for-communal-constitutionalism/ (1. prosinca 2018.), DOI: http://dx.doi.org/10.17176/20161111-103534. 
Burdeau, G., Traite de science politique, vol. 4, L. G. D. J., 1952.

Ćapeta, T.; Rodin, S., Osnove prava Europske unije, 2. izdanje, Narodne novine, 2011.

Diamond, M., The Revolution of Sober Expectations, predavanje dostupno na: www. aei.org/publication/the-revolution-of-sober-expectations, Oct 24, 1973 (1. 12. 2018.).

Elster, J.; Slagstad, R. (ur.), Constitutionalism and Democracy, Cambridge University Press, 1988.

Europska komisija, Bijela knjiga o budućnosti Europe, 1. ožujka 2017., dostupno na: https://ec.europa.eu/commission/sites/beta-political/files/bijela_knjiga_o_buducnosti_europe_hr.pdf (1. 12.2018.).

Fichera, M., The Paradox of Liberal Constitutionalism: a Call for Communal Constitutionalism, VerfBlog, 10. 11. 2016., dostupno na: https://verfassungsblog.de/ the-paradox-of-liberal- constitutionalism-a-call-for-communal-constitutionalism/ (1. 12. 2018.), DOI: http://dx.doi.org/10.17176/20161111-103534.

Ginsburg, T.; Huq, A. Z., How to Save a Constitutional Democracy, University of Chicago Press, 2018.

Ginsburg, T.; Huq, A.; Versteeg, M., The Coming Demise of Liberal Constitutionalism?, The University of Chicago Law Review, vol. 85, br. 2, 2018., str. $239-255$.

Graber, M. A.; Levinson, S.; Tushnet, M. (ur.), Constitutional Democracy in Crisis?, Oxford University Press, 2018.

Häberle, P., The Constitutional State and Its Reform Requirements, Ratio Juris, vol. 13, br. 1, 2000., str. $77-94$.

Häberle, P., Ustavna država, Politička kultura, 2002.

Hernández G., J. I., Towards a Concept of Constitutional Authoritarianism: The Venezuelan Experience, Blog of the International Journal of Constitutional Law, Dec. 14, 2018, dostupno na: http://www.iconnectblog.com/2018/12/towards-a-concept-of-constitutional-authoritarianism-the-venezuelan-experience/ (1. 12. 2018.).

Huntington, S., The Clash of Civilizations and the Remaking of World Order, Simon \& Shuster, 1997.

Koh, H. H., Can the Commander in Chief Be the Chief Torturer?, Indiana Law Journal, vol. 81, 2006, str. 1145 - 1167.

Krastev, K.; Holmes, S., Explaining Eastern Europe: Imitation and Its Discontents, Journal of Democracy, vol. 29, br. 3, 2018., str. 117 - 128.

Kregar, J.; Ravlić, S.; Puljiz, V. (ur.), Hrvatska: kako dalje - zadanosti i mogućnosti, Pravni fakultet Sveučilišta u Zagrebu, Centar za demokraciju i pravo "Miko Tripalo", 2004. 
Kube, H., The EU Financial Crisis - European Law and Constitutional Law Implications, Mario Einaudi Center for International Studies, Cornell University, 2012.

Loewenstein, K., Political Power and Governmental Process, University of Chicago Press, 1957.

Mecham, Q., Jačanje islamističkih aktera: prijedlozi za američku strategiju održive suradnje, Političke analize, vol. 3, br. 11, 2012., str. $26-30$.

Mratović, V. (ur.), Problemi suvremene države, Naprijed, 1971.

Mratović, V.; Smerdel, B.; Bačić, A.; Crnić, J.; Filipović, N.; Lauc, Z., Stručne osnove mogućeg prijedloga ustavnih promjena, Zbornik Pravnog fakulteta u Zagrebu, vol. 50, br. 3, 2000., str. $373-392$.

Ostrom, V., The Meaning of Democracy and the Vulnerabilities of Democracies, A Response to Tocqueville's Challenge, University of Michigan Press, 1997.

Oxford Manifesto 1997 of the Liberal Internationale, The Liberal Agenda for the 21st Century, dostupno na: https://liberal-international.org/who-we-are/...manifestos/oxford-manifesto-1997/ (1. 12. 2018.).

Picula, B., Božja stranka na čelu Libanona - od rata do vlasti, Političke analize, vol. 3, br. 11, 2012., str. $30-37$.

Posner, R., recenzija Ackerman, B., The Future of Liberal Revolution, East European Constitutional Review, vol. I, br. 3, 1992., str. 35 - 36.

Quaglia, L., Central Banking Governance in the European Union: A Comparative Analysis, Routledge, Uaces Contemporary European Studies, 2017.

Raunić, R., Edmund Burke: Razmatranja o revoluciji u Francuskoj, dostupno na: http://www.ffzg.unizg.hr/filoz/wp-content/uploads/2011/11/Raunic\%CC\%81_E.-Burke.pdf_(1. 12. 2018.).

Ravlić, S.; Kregar, J.; Flego, G. (ur.), Hrvatska: Kako sada dalje?, Pravni fakultet Sveučilišta u Zagrebu, Centar za demokraciju i pravo "Miko Tripalo", 2008.

Scicluna, N., European Union: Constitutionalism in Crisis, Routledge, 2015.

Smerdel, B., Akutna kriza vlasti izraz je kronične krize hrvatskog konstitucionalizma, Hrvatska pravna revija, vol. 17, br. 6, 2017., str. 1 - 13.

Smerdel, B., Central European Democratic Transition: The Paradigm of Constitutional Revolution, Paper presented at the Round Table of the International Association of Constitutional Law, Belgrade, Serbia, May 2012.

Smerdel, B., Constitutional Identity: Beyond the View From the Constitutional Courts, VIII. Congress of Constitutional and European Law, Sveučilište Regensburg, Njemačka, 22. 03. 2012., dostupno na: https://www.pravo.unizg.hr/_download/repository/Constitutional_identity.doc (1. 12. 2018.). 
Smerdel, B., European Union: the continuing process of constitutional choice, WOW Conference, Bloomington, Indiana, June 2006, dostupno na: https://www. pravo.unizg.hr/_download/repository/EUROPEAN_UNION_THE_CONTINUING_PROCESS.doc (1. 12. 2018.)

Smerdel, B., Hrvatski konstitucionalizam danas. U svijetlu Prijedloga ustavnih promjena, Informator, br. 6249 od 25. siječnja 2014., str. I - 2.

Smerdel, B., Hrvatski pravni sustav i ustavno načelo vladavine prava, Zbornik Pravnog fakulteta u Zagrebu, vol. 51, br. 6, 2001., str. 1149 - 1162.

Smerdel, B., Kako na ustavan način izabrati suce Ustavnog suda, Hrvatska pravna revija, vol. 16, br. 3, 2016., str. 5 - 10.

Smerdel, B., Konstitucionalizam i promjena vlasti, Zbornik Pravnog fakulteta u Zagrebu, vol. 50, br. 1-2, 2000., str. 5 - 28.

Smerdel, B., Konstitucionalizam i stabilnost ustava, u: Europske perspektive demokratske Hrvatske, Hans Seidel Stiftung, 2001., str. 93 - 101.

Smerdel, B., Kraj tranzicije i nužnost konsolidacije ustavnog poretka, Hrvatska pravna revija, br. 8,2012 ., str. $1-10$.

Smerdel, B., Nove demokracije, konstitucionalizam i organizacija vlasti, Zakonitost, vol. 47, br. 1, 1993., str. $5-22$.

Smerdel, B., O neustavnosti Zakona o sprečavanju sukoba interesa, Informator, vol. 59, br. 5977, 2011., str. 1 - 32.

Smerdel, B., O ustavima i ljudima, Informator, 2012.

Smerdel, B., Primjena federalnog načela i ustavni amandmani iz 1971., u: Smerdel, B. (ur.), Primjena federalnog načela i pouke ustavne reforme 1971., Pravni fakultet Zagreb i Centar Miko Tripalo, 2007., str. 17 - 38.

Smerdel, B., Promjena vlasti i izgledi ustavnog poretka, u: Kregar, J.; Ravlić, S. (ur.), Hrvatska: Kamo dalje?, Centar Miko Tripalo, Zagreb, 2004., str. 192 - 193.

Smerdel, B., Smjena vlasti, demokracija i vladavina prava, Informator, br. 6027 od 10. prosinca 2011., str. $1-2$.

Smerdel, B., Temeljni problemi ustavnog izbora u Europskoj uniji: pokušaj preliminarne prosudbe rezultata Konvencije o budućnosti Europe, Zbornik Pravnog fakulteta $\mathrm{u}$ Zagrebu, vol. 53, br. 3-4, 2003., str. 509 - 527.

Smerdel, B., Ustavna revolucija, demokratska tranzicija i vladavina prava, u: Uzelac, A.; Garašić, J.; Maganić, A. (ur.), Djelotvorna pravna zaštita u pravičnom postupku, Liber amicorum Mihajlo Dika, Pravni fakultet u Zagrebu, 2013., str. 27 - 45.

Smerdel, B., Ustavni eksperiment socijalističkog samoupravljanja, Zbornik Pravnog fakulteta u Zagrebu, vol. 38, br. 3, 1988., str. 317 - 333. 
Smerdel, B., Ustavno uređenje europske Hrvatske, Narodne novine, Zagreb 2013.

Smerdel, B.; Gardašević, Đ. (ur.)., Izgradnja demokratskih ustavnopravnih institucija Republike Hrvatske u razvojnoj perspektivi - izabrani radovi projekta MZOŠ broj 066-0661428-2502 (2007.-2011.), Hrvatska udruga za ustavno pravo, 2011.

Sokol, S.; Smerdel, B., Ustavno pravo, Školska knjiga, 1992.

Woodward, B., Obama's Wars. The Inside Story, Simon \& Shuster, 2010.

Zurcher, A. J., Constitutions and Constitutional Trends since WW II, New York University Press, 1951. 
Summary

\section{Branko Smerdel *}

\section{THE CRISIS OF DEMOCRATIC CONSTITUTIONALISM AND THE PROSPECTS OF FURTHER DEMOCRATIC TRANSITION IN CROATIA}

Thirty years after the "constitutional revolutions" of the 1990s, the best part of the modern political and social theory prevalently turns its focus to the evident crisis of democracy and constitutionalism in the modern world. Not only had the excessive expectations not been justified, but the very viability of the concept of liberal democratic constitutionalism was brought into question.

Croatia has been slow and continues to fall behind due to a decade of efforts to victoriously complete the process of establishing an independent and sovereign state during the struggle against foreign aggression and domestic rebellion by a part of the population. This problem has been exacerbated by the political and economic developments in the neighbouring countries.

The consequence of the longest negotiations on accession to the European Union membership to date was that the Union into which Croatia was finally admitted is very different from the one for whose membership it had applied. After a brief analysis of the new challenges which have profoundly changed the European Union, the author pleads for a realistic orientation in constitutional and political theory, which in his view must offer radical answers to these challenges in order to provide intellectual grounds for dealing with this crisis, while preserving the fundamental elements of liberal democratic constitutionalism.

Key words: crisis, constitutionalism, democracy, European Union, Croatia

* Branko Smerdel, Ph. D., Professor, Faculty of Law, University of Zagreb, Trg Republike Hrvatske 14, Zagreb; branko.smerdel@pravo.hr;

ORCID ID: orcid.org/0000-0002-1836-1248 
